\section{Electrical Responses to Odours of Degenerating Olfactory Epithelium}

Hosoya and Yoshida ${ }^{1}$, and especially Ottoson ${ }^{2}$, showed that a slow potential appears in the olfactory epithelium when an odour is applied. A sirnilar slow potential was found at the cessation of odour application in our laboratory ${ }^{3-5}$. These potentials were eloctronegative when recorded by means of a macro-electrode placed on the surface of the olfactory epithelium. Later, an electropositive slow potential was found in our laboratory when some kind of odours were applied ${ }^{6,7}$. Consoquently, three kinds of responses, electronegative on-, electropositive onand electronegative off-slow potentials were found in the olfactory epithelium of the frog, toad, fish and newt.

The olfactory epithelium is composed of three kinds of cells, the olfactory, the sustentacular and the basal cells; those which reach the epithelial surface are the former two. The olfactory cell is genorally supposed to be the olfactory receptor. The sustentacular cell is also supposed to play a part in olfaction as well. This supposition is based on some evidence and research works s, $^{8,9}$ which show that the olfactory pigment contained in the sustentacular cell is concerned with olfaction. Consequently, it is probable that the sustentacular cell also produces some kind of electrical potential in response to odour stimulation.

When the olfactory nerve is cut, the olfactory cell undergoes degeneration, and the sustentacular cell remains ${ }^{10,11}$. If olfactory responses are examined in this degenerated olfactory epithelium, it can probably be clarified whether the remaining cell produces any electrical activity or not.

Bullfrogs were used. The olfactory nerve of one side was sectioned as peripherally as possible. A series of experiments was started several days after nerve section. One or two bullfrogs were used in each experiment. In the first and second groups of bullfrogs, the slow potentials disappeared in about eight days after sectioning (Fig. 1). These experiments were performed in the summer. In the third group of bullfrogs, the slow potentials dis appeared in about eleven days, and in the fourth group in about sixteen days. These experimonts were performed in early autumn and in early winter. The average temperatures in which the bullfrogs were reared were about $22^{\circ} \mathrm{C}$ in the second group and about $11^{\circ} \mathrm{C}$ in the fourth one. On the other hand, a number of days elapsed before the disappearance of the slow potential; namely,

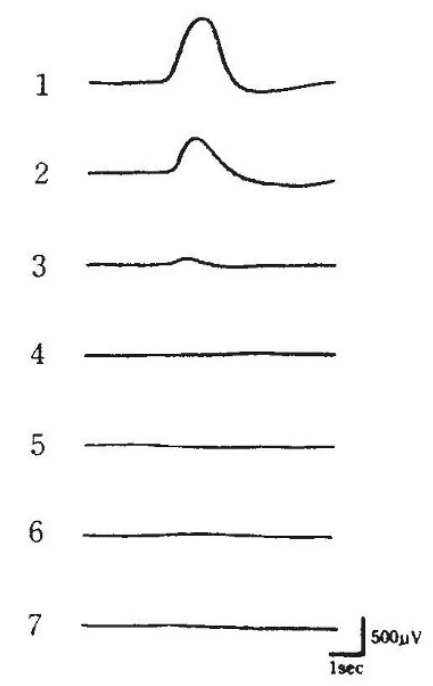

Fig. 1. Electrical responses produced in the degenerating olfactory epithelia of a bullfrog. Records $1-7$ were obtained in the degenerating the olfactory nerve. It is seen that the olfactory response becomes smaller and disappears in eight days after the sectioning

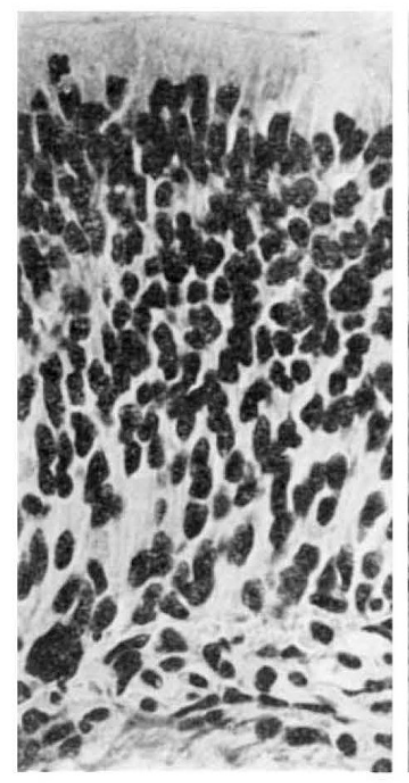

A

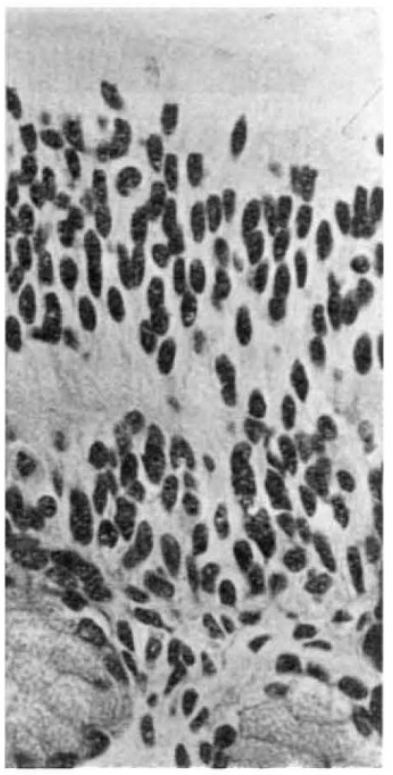

B
Fig. 2. Sections of the olfactory epithelia. They were obtained in a bullfrog the olfactory nerve of which of the right side was cut nine days before. In the sectioned side, slow potential appeared no more as shown in the record No. 5 of Fig. 1. A, Normal side: slender nuclei of sustentacular cells are seen towards the top and round nuclei of the olfactory cells underneath them. Number of cells is quite large. $B$, Sectioned side: note the striking decrease in the number of cells. Those remaining are practically only cells with slender nuclei. A few cells with round nuclei are scattered in the whole epithelium. They probably belong to basal cells. Stained by gallocyanin

eight in the former group and sixteen in the latter. Consequently, the $Q_{10}$ of the speed of nerve degeneration is approximately 2 . In all these experiments, when the electronegative on-slow potential disappeared the other two kinds of potentials also disappeared

All the olfactory epithelia were fixed after the recording of electrical activity and stained by several methods; in most cases, they were stained by gallocyanin. In these preparations, discrimination between the olfactory and the sustentacular cell was not difficult in many cases, because the nucleus of the former cell looked round and chestnut-like, and that of the latter slender and glass cuplike. In the sections of the epithelia in which the slow potential was no more observed, considerable decrease in the number of cells was found and the remaining cells were practically identified to be the sustentacular and the basal cells (Fig. 2). From these electrophysiological and histological studies, it was concluded that not only the electro-negative 'on' - and 'off'-slow potentials but the electropositive 'on'-slow potentials originate in the olfactory cell.

SADAYUKI F. TAKagi TOSHI YAJIMA

Department of Physiology,

School of Medicine,

Gunma University, Maebashi Japan.

Hosoya, Y., and Yoshida, H., Jap. J. Med. Sci., III Biophys., 5, 22 (1937)

2 Ottoson, D., Acta Physiol. Scand., 35, Supp., 122 (1956).

${ }^{3}$ Takagi, S. F., and Shibuya, T., Nature, 184, 60 (1959).

${ }^{4}$ Takagi, S. F., and Shibuya, T., Electrical Activity of Single Cells, edit. by Katsuki, Y. (Igakushoin, Tokyo).

- Shibuya, T., Jap. J. Physiol., 10, 317 (1960).

- Takagi, S. F., Shibuya, T., Higashino, S., and Arai, 'T., Jap. J. Physiol. 10, $571(1960)$.

'Shibuya, T., and Takagi, S. F., J. Gen. Physiol., 47, 71 (1963).

'Allison, A. C., Biol. Rev., 28, 195 (1953).

- Onagawa, K., J. Physiol. Soc. Japan, 19, 189, 194 (1957).

${ }^{10}$ Nagahara, Y., Jap. J. Med. Sci. (Sect. 5), 5, 165 (1940).

${ }^{11}$ Clark, W. E. Le Gros, Proc. Rov. Soc., B. 146. 299 (1957). 